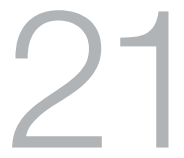

\title{
Performing Cannibalism in the South Seas
}

\author{
Tracey Banivanua Mar
}

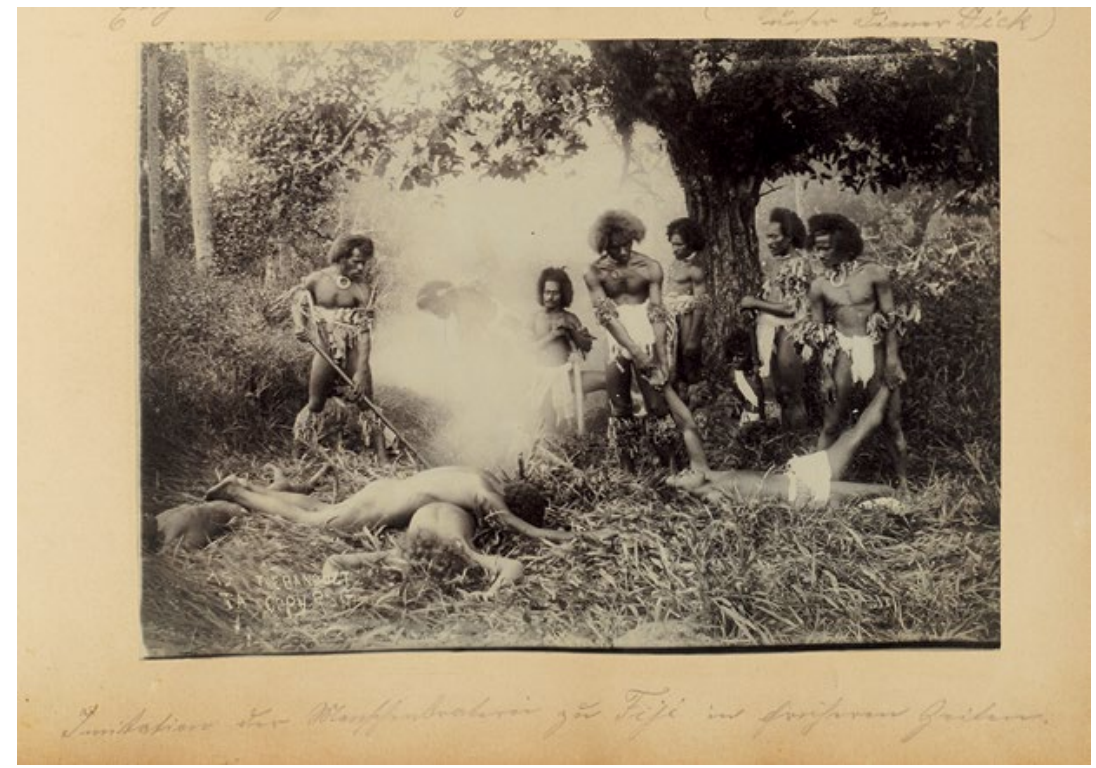

Figure 108. Imitation of roasting humans at Fiji in former times.

Source. Forming part of the library's collection 'Views and portraits of the Pacific Islands' by Paula David; call number PXE 708/item 15b; digital order number a698017, with permission State Library of New South Wales, Mitchell Library, PXE 708. 
Climbing the hills out of Sigatoka on Fiji's main island of Viti Levu, the view is stunning. The Sigatoka River snakes its way from the hills to the coast, carving a spectacular valley and sharply steep hills. I was bumping along in a poorly ventilated, muggy as hell minibus with a small group of tourists when I first saw this river. It had been raining for days before. The Sigatoka River was a seething mass of fast-moving water, and the potholed road beneath our bus was only barely attached to the landscape. My fellow travellers were two teenagers, a couple of grey nomads, a sunburnt resort couple and a lady on safari, who was otherwise nondescript except for her archetypal clothing of white linen and a pith-helmet-esque hat, a vision of empire in the tropics. Just out of Sigatoka we had stopped to pick up two more passengers, Fijians Jone and Semi. For some reason they boarded with an inflated tyre tube. They were mates of Sam, our tour guide. Sam had arrived late on this Sunday morning, with bloodshot eyes and a remnant dusting of blue glitter on his face and neck. The camp flourishes with which he waved goodbye to his ride became muted on the bus as he donned his professional tour guide face and welcomed us to a cannibal adventure of a lifetime.

We were going to Fiji's Naihehe Caves, a spectacular and sacred cave system in the hills where, I had read, the Sawaitabu people took refuge against a raging measles epidemic in the 1870s. The measles had arrived from Sydney at the same time as Fiji became a British Crown Colony. It was contracted by chiefs and their entourage at roving ceremonies held to sign the Deed of Cession, the legal instrument ceding Fijian sovereignty to Britain. Infected chiefs unwittingly carried measles back to their villages, devastating their communities. The disease went on to wipe out nearly half the population of Fiji. The Sawaitabu people, viewing the epidemic as a colonial disease, took refuge in the Naihehe Caves, renouncing empire and Christ. In Fiji by the 1870s and 1880s, such resistance was increasingly coupled with the idea of cannibalism and therefore bound for destruction. Protected by the caves with their secret and narrow entrances the Sawaitabu people held out against colonial intrusions until eventually, exhausted by sustained bloody conflict, they surrendered. Today the caves are marketed to tourists as the Cannibal Caves. ${ }^{1}$

1 Repeka Nasiko, 2012, 'The caves of Naihehe', The Fiji Times, 19 February. 
Cannibalism has always been a drawcard for outsiders in the Pacific and for much of the nineteenth century the Fiji islands were nicknamed the 'Cannibal Islands'. A concentration of missionary and planter activity had made them the notorious epicentre of Europe's Pacific craze by mid-century. Travel writers, missionaries, settlers and labour traders published memoirs and travel narratives for ever-attentive audiences. They filled these accounts with titillating tales of cannibal adventures, and illustrated them with pictures of cannibal forks and other paraphernalia. ${ }^{2}$ Postcards like 'The Banquet', and travelling human exhibits like the Fiji Cannibal Exhibition of 1873 took the tourist experience to audiences in Europe and America. So, too, accounts of the Pacific's cannibalistic Manners and Customs, as they were nearly always titled, ranged in quality from the formulaic to the absurd, but most simply repeated tales of cannibalism as hearsay of a pagan past. Some writers such as the American William Endicott indulged openly in varying degrees of fantasy many years after their travels, while others, missionaries included, wrote more soberly of practices indicative of a savagery whose days were numbered.

So invested and entwined with colonial projects were the prolific accounts of cannibalism in the Pacific and elsewhere that William Arens was moved in 1979 to controversially - some would say sacrilegiously-claim that cannibalism was a hoax, a projected fantasy. ${ }^{3}$ Cannibalism was a meta-myth, he argued, a ritualistic practice specific to colonial encounters. Those whose job it is to document native man-eating practices have been outraged by his suggestion that cannibalism did not and never did exist. But a more subtle point he made endures. Viewing cannibalism says more about the rituals of the viewer than the viewed.

The Naihehe Caves still belong to the people of the Navosa Highlands, and after an hour of travelling we stopped near Natawatawa village to present i-sevusevu, a short ceremony to request and receive permission to visit the caves. We were all asked to wear a sulu for the fairly casual ceremony, receiving at the end a bowl of grog-not the good stuff, the peppery waka, but the touristy muddy yaqona that made Safari Lady wince. After this we crossed the seething Sigatoka

\footnotetext{
2 'Cannibals with Cutlery', 2013, Daily Mail, 9 January.

3 William E. Arens, 1979, The Man-eating Myth: Anthropology and Anthropophagy, New York: Oxford University Press.
} 
River with our hearts in our throats, and walked the remaining distance along a well-worn and now muddy and slippery path to the opening of the caves. This is a crevice in the hillside and we crouched and shuffled along a stream and through the puckered entry into the long, narrow rock halls beyond. Inside, under torchlight, Sam ramped up the cannibal jokes and stories. As we moved through the halls and taverns of the caves, Sam picked out sparkling formations of limestone and stalagmites, the 'cannibal man' and 'cannibal woman'. Cameras flashed. As we moved through the caves, Sam continually asked us to imagine a whole village living in these spaces, sequestered in the dark, for months on end. Imagine the hunger.

The tour of the cave culminated in a wide and open cavern, the main living space for the village. We were offered more tantalising stories of cannibalism before being shown what had been the kitchen with its natural chimney and oven formation. Here the cannibal stories reached a crescendo. Camera flashes flickered and we were asked to imagine body parts in the oven. Sam acted it out. Safari Lady played along. These cannibals were not evil, she gravely informed us, they just did not know any better. Thank god for the missionaries. Sam pointed at a stalagmite formation with a round flat surface, and suggested maybe it was a cannibal stone, a site of sacrifice, or where bodies were carved and prepared for cooking. He acted it out. He showed us some more chambers, the dining chamber with more references to cannibalism, the sleeping chambers and a secret entrance. The cannibal jokes continued and segued seamlessly into discussion, and more jokes, about lunch. 'Who's for lunch?' Sam said. 'Naah, I meant who wants lunch?' he added, assuring us he had never eaten anyone.

I took this tour nearly 20 years after Dennis O'Rourke's Cannibal Tours filmed and framed a group of rich, white travellers 'touring' the Sepik River in Papua New Guinea. ${ }^{4}$ Tales of cannibalism had migrated west across the Pacific over time, coming to rest in the late twentieth century on the island that is now split along the 14lst Meridian between West Papua and Papua New Guinea. In O'Rourke's film, each tourist has their own agenda, and acts according to latent narratives of savagery and primitiveness. Unsettlingly lingering shots make us observe the tourists observing Papuans. In a pair of loud Americans

4 Dennis O'Rourke, 1988, Cannibal Tours, directed and produced by Dennis O'Rourke in association with the Institute of Papua New Guinea Studies. 
in search of primitive art, and another safari-suited German obsessed with seeking cannibalism and ticking off a checklist of toured, read, conquered regions of the world, we witness an Arens-like ritual being played out. The tourists see what they came to see whether or not Papuans play their part, and Papuans act out their roles knowingly and begrudgingly.

The parallels between cannibal tours up the Sepik River in 1988 and the Cannibal Caves tour 20 years later are all there, even the safari suit. But it was not quite a ritual in which we obediently and religiously replicated a prescribed order. Rather this kind of cultural tourism, which thrives in the Pacific, is more like a performance that has been rehearsed countless times. The script is simple and generic, and is transportable across the islands with empty text-fields that are filled in locally. Cannibalism thrived here among the benighted savages of this place, empire/missionaries arrived in the colonial period, today we are civilised/Christian. Postscript: there may still be some who practice it in the remote hills of the interior.

The present mirrors the past in the Pacific and the promise of encountering cannibals, of the past or in the present, remains alluring. Even as Pacific Islanders have developed sophisticated ways of presenting, celebrating and offering culture to curious tourists, and tourists have developed more nuanced interests, the appeal of discovering, encountering and imagining cannibals endures and has adapted. Tour companies in West Papua sell 'First Contact Tours' as part of a burgeoning adventure tourism trade. They promise to make contact with stone-age primitives and cannibals who have never seen white people before. The tours sell a fantasy of course. And it is lucrative. Since 2000, numerous books, documentaries and Discovery Channel sagas of white men Going Tribal ${ }^{5}$ amongst cannibals, set in Papua New Guinea or West Papua have fed the market. The UK-based magazine Zoo Weekly offered a 'cannibal sex holiday!' in West Papua as a competition prize in $2004 .{ }^{6} \mathrm{~A}$ collection of Fijian cannibal forks sold in the UK for $£ 30,000$ in 2013. In the same year international news outlets broadcast under sensational headlines, 'Tourist feared eaten by cannibals' that a German tourist had been killed and eaten

5 Going Tribal is a popular documentary series, in which the host visits and emulates imagined 'tribal' peoples, that was produced in the early 2000s and aired on the BBC and Discovery Channel.

6 Paul Kingsnorth, 2004, 'Spot the real savages', New Statesman, 15 March. 
by cannibals in French Polynesia. Social media lit up. On the White Pride website Stormfront, 'Remey 74' wondered why white people go to 'these third world countries and not expect' to be eaten.

The reality of cannibal fantasies is stark. Michael Behar, having taken a cannibal contact tour in 2004, wondered in hindsight whether the elaborate feathered headdresses worn by the cannibals he encountered were just a little too ceremonial for a believable casual encounter. ${ }^{7}$ In 2004 Benny Wenda, a West Papuan pro-independence leader seeking asylum in the UK, visited the office of Zoo Weekly, seeking an apology for the magazine's marketing of West Papua as the titillating home of tribes of cannibals. He did so bearing the torture scars he had received from the Indonesian military, and showing photographs of Papuan torture victims, he reminded the magazine's editor Paul Merrill, that Papuans were actually victims of an unfolding genocide. He received the apology he came for. Finally, the cannibals of the romantic South Seas that ate German tourist Stefan Ramin, was actually the opportunistic and now convicted murderer Henri Haiti. ${ }^{8}$ Neither the prosecution nor the defence at his trial took seriously the claims that he was a cannibal. The burnt-out fireplace with charred bones on Nuku Hiva that had prompted sensational claims of cannibalism was merely the site where Haiti had tried to destroy the evidence of his crime. $^{9}$

Pointing out the contextual reality of performances of cannibalism in the Pacific is not about trying to prove that the practice never existed. In a sense that question has become irrelevant. Claims of cannibalism today are a little playful and tongue-in-cheek, and both tourists and the toured play along for mutual gain. At the Naihehe Caves, we all played along, although to varying degrees. Sam played his part as the guide. He helped us as tourists to frame the caves in two dimensions, pointing to the innocuous props to point our cameras at. His jokes about being hungry lightened the mood and invited us to project the simple cannibal narrative on to him. As a guide he was both

\footnotetext{
7 Michael Behar, 2005, 'The selling of the last savage', Outside Magazine, 1 February.

8 'Henri Haiti jailed for murder', 2014, Cook Island News, 19 May.

9 'Tourist feared eaten by cannibals', 2011, The Fiji Times Online, 18 October; 'Tales of cannibalism from the South Pacific', 2011, Telegraph, 18 October; 'Hunter suspected of killing and eating mission German Tourist has tattoo of notorious cannibal tribe who ate victims', 2011, Mail Online, 21 October; 'Cannibal claims: We'd rather eat hot dogs than humans, say Pacific Islanders', 2011, Daily Telegraph, 18 October.
} 
narrator and narrated, embodying the fantasy we had paid for. Safari Lady's accidental or deliberate appearance cast her as Sam's direct counterpart, and she was also narrator and narrated. Such encounters seem both humorous and harmless. They allow tourists who are normally encouraged to stay cloistered in the shelters of sun-drenched resorts to feel they have encountered something of Fijian culture. But as we arrived back at the river and all piled on to a raft for the last part of the tour, the underlying structure of the entire performance became more apparent.

The last part of the Cannibal Caves tour was a short ride on a raft down the Sigatoka River. Normally this would be a leisurely lolling ride propelled by a gentle undertow. But on this day the river was swollen, its water hurtling towards the sea. Our raft looked flimsy, and it strained on its mooring as the water snatched and tugged at it. Jone and Semi had found some more tyre tubes, some of which had been tied to the raft to help it stay afloat. As we all piled on the raft, the two teenagers were invited to hop into the tyres. Jone and Semi swam, pushing the tyres and the teenagers, and Sam towed the rest of us on the raft, holding on to his own tyre. That is how the discomfort I had felt in the caves, and the increasing and unprovoked animosity I was feeling for Safari Lady crystallised. This tour was modern. It respected the customs of landowners, and Sam, Jone and Semi were cosmopolitan urban-dwellers. But there we were dry and high, Safari Lady still pristine and white, and there Sam, Semi and Jone were huffing and puffing in the muddy water to get us across the river. The cannibal tour had cast us all, tourists and toured, outsiders and locals, in a colonial re-enactment.

Touring the Pacific has a history that is tangled up with colonialism. Since at least the nineteenth century, visitors have projected any number of cultural and sexual fantasies onto sites of encounter in the Pacific. Until recently, those visitors arrived on vessels that were threading and weaving the islands of the Pacific evermore tightly into global networks of empire. Escaping the binds of civilisation to the unbound Pacific, whether as a missionary, beachcomber or tortured artist, has been a central trope of travel literature for at least two centuries. Fantasies of, and encounters with, cannibalism belong to the dark heart of these tours. I have written elsewhere about the 
entanglements of cannibalism and colonialism, ${ }^{10}$ as have the authors that contributed to the book Cannibalism and the Colonial World in 1998. ${ }^{11}$ During the colonial era, touring cannibalism was always about locating virgin sites of conquest, or touring its aftermath. Violence, often extreme, against de-humanised cannibals was eminently just. And encountering ex-cannibals allowed narrators of travel accounts to marvel at the civilisational distance that contact with Europe had afforded. In ex-cannibals they could encounter embodied evolution, living empirical evidence of the benefits of the civilising mission. But this history of cannibalism is elided by fantasy tours of today.

The Cannibal Caves tour ended with the river ride. Miraculously Sam, Semi and Jone got us safely to the other side without being swept away, and afterwards we tourists consumed a prepared lunch together. Our tour guides ate separately. Their performance was over, more or less, and on the bus ride back to the resorts they chatted amongst themselves in Fijian, mostly about their social lives. As the tour receded, our complex subjectivities returned to us all, not least to the caves themselves. In the absence of performances of cannibal tourism, the Naihehe Caves contain the rock art, spirits, stories and legends of their peoples, to whom they provided life-saving refuge from a vicious and uncompromising plague. ${ }^{12}$ They are therefore also an important historical site testifying to the ingenuity of the Sawaitabu people who occupied them. They are now a complex site of resistance to and accommodation of colonial rule. But yoked to the enduring narrative of cannibal encounters they lose these layered dimensions.

Cannibal tourism re-stages an uneasy colonial past. The encounters are more than simply a tongue-in-cheek performance in which all actors innocently carry equal agency. Instead, both tourists and the toured engage in a triumphalist animation, a cartoon rehearsal of the colonial encounter, that puts natives back in their place. The jokey humour that almost always accompanies the performance or evocation of cannibal

10 Tracey Banivanua Mar, 2008, “A thousand miles of cannibal lands": Imagining away genocide in the re-colonisation of West Papua', Journal of Genocide Research 10(4): 583-602; Tracey Banivanua Mar, 2010, 'Cannibalism and colonialism: Charting colonies and frontiers in Nineteenth-Century Fiji', Comparative Studies in Society and History 52(2): 255-81.

11 Francis Barker, Peter Hulme and Margaret Iversen (eds), 1998, Cannibalism and the Colonial World, Cambridge: Cambridge University Press.

12 María Cruz Berrocal and Sidsel Millerstrom, 2013, 'The archaeology of rock art in Fiji: Evidence, methods and hypotheses', Archaeology in Oceania 48(3): 154-65 
tours, moreover, belittles, trivialises and de-humanises complex cultures and histories. Admittedly, the humour is as much directed at the self-conscious tourist as the toured, but they nevertheless call into being the roles of colonised and coloniser, observed and observer, toured and tourist.

\section{References}

Arens, William E. 1979. The Man-eating Myth: Anthropology and Anthropophagy. New York: Oxford University Press.

Banivanua Mar, Tracey. 2008. "A thousand miles of cannibal lands": Imagining away genocide in the re-colonisation of West Papua.' Journal of Genocide Research 10(4): 583-602.

- 2010. 'Cannibalism and colonialism: Charting colonies and frontiers in Nineteenth-Century Fiji.' Comparative Studies in Society and History 52(2): 255-81.

Barker, Francis, Peter Hulme and Margaret Iversen (eds). 1998. Cannibalism and the Colonial World. Cambridge: Cambridge University Press.

Behar, Michael. 2005. 'The selling of the last savage.' Outside Magazine. 1 February.

Berrocal, María Cruz and Sidsel Millerstrom. 2013. 'The archaeology of rock art in Fiji: Evidence, methods and hypotheses.' Archaeology in Oceania 48(3): 154-65

Cruz Berrocal, María and Sidsel Millerstrom. 2013. 'The archaeology of rock art in Fiji: Evidence, methods and hypotheses.' Archaeology in Oceania 48(3): 154-65.

David, Paula. c. 1890-1899. Views and Portraits of the Pacific Islands. Mitchell Library, State Library of New South Wales.

O'Rourke, Dennis. 1988. Cannibal Tours. Directed and produced by Dennis O'Rourke in association with the Institute of Papua New Guinea Studies. 
This text is taken from Touring Pacific Cultures, edited by Kalissa Alexeyeff and John Taylor, published 2016 by ANU Press, The Australian National University, Canberra, Australia. 